\title{
Intra-articular injection in the knee of adipose derived stromal cells (stromal vascular fraction) and platelet rich plasin a for osteoarthritis
}

Himanshu Bansal ${ }^{{ }^{*}}$, Kristin Comella², Jerry Leon ${ }^{3}$, Poonam Verma', Diwaker Ag:awa. Prasad Koka ${ }^{5}$ and Thomas Ichim 6

\begin{abstract}
Background: Stromal vascular fraction (SVF) can easily be obtained from a mi -lipoaspirate procedure of fat tissue and platelet rich plasma (PRP) can be obtained from peripheral bloo r.n. aluated the safety and preliminary efficacy of administering SVF and PRP intra-articularly into patients with csteoarthritis grade 1 and 2.

Methods: A total of ten patients underwent a local tumesrent liposuetion procedure to remove approximately $100 \mathrm{ml}$ of fat tissue from the abdomen. SVF was isolate usin n enzyme digestion and resuspended in PRP for intra-articular injection in the knee. The Western Ontarlo d M Master Universities Osteoarthritis Index (WOMAC) score and six-minute walk distance (6MWD) were ased to ' ate clinical effects and included measure of patient's subjective assessment of pain, joint mobility, an ho icall disability. WOMAC score, 6MWD and laboratory tests were repeated at 3 and 6 months and 1,1.5 and 2ycars. AY and MRI were completed at 1 year.

Results: The average total WOMAC score 64 at baseline and significantly reduced to 52 at 3 months, 46 at 6 months, 42 at 1 year, 38 at 1.5 years, nd 41 a vears. Patients walked an average of 1310 feet at baseline and demonstrated a statistically significant i nprovementat 3 and 6 months and 1, 1.5, and 2 years post treatment. Cartilage thickness as determined by MRI in roved b/ at least $0.2 \mathrm{~mm}$ in six patients, was unchanged in two patients and decreased by at least $0.2 \mathrm{~mm}$ in two tien $\mathrm{s}$.
\end{abstract}

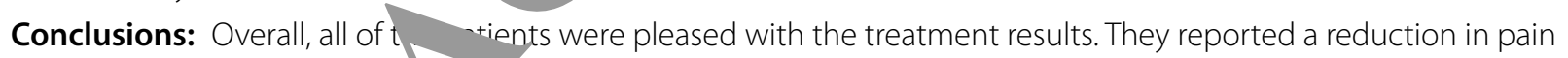
levels, especially after 3 month $/$ Mo,e importantly, the procedure demonstrated a strong safety profile with no severe adverse events or conp ation reported.

Trial registration NC, Name of registry: http://www.clinicaltrials.gov

Keywords: Smal vas Jär fraction (SVF), Adipose derived stromal/stem cells (ADSCs), Stem cells, Adipose tissue, Connective tisso Osteoarthritis, Cell therapy, Platelet rich plasma (PRP)

\section{Backgrc d}

Qou rthri $(\mathrm{OA})$ is a degenerative disease characthe slow progressive destruction of articular

car ge accompanied by changes to synovium and sub

*Correspondence: hbansal@drhbf.org

${ }^{7}$ Mother Cell Spinal Injury \& Stem Cell Research, Anupam Hospital,

Second Floor, Kashipur Bypass Road, Rudrapur, Uttarakhand 263153, India

Full list of author information is available at the end of the article chondral bone, degeneration of ligaments and menisci and hypertrophy of the joint capsule $[1,2]$. The pathogenesis is usually characterized by severe inflammation, recruitment of inflammatory cells, pro inflammatory cytokine production and activation of proteinase that results in extracellular matrix (ECM) degradation and ultimately apoptotic cell death of differentiated chondrocytes. OA is influenced by genes, environment (e.g. aging 
and obesity) and local trauma (e.g. consequences of joint injury/joint laxity or mal-alignment). These factors and more may contribute to the pathological process involved in the degeneration of the knee [3, 4].

Typical treatments include weight reduction, rest, exercise, non-steroidal anti-inflammatory drugs (NSAIDS), intracellular glucocorticoid injections, visco supplements, physical therapy and bracing. These modes of treatments are usually palliative and merely provide symptomatic relief from pain, failing to prevent cartilage damage and subsequent destruction of other joint tissues [5-7].

Surgical methods of repair include the transplantation of osteochondral grafts, microfracture, and autologous chondrocyte implantation. All of these techniques are limited to the repair of focal lesions. According to controlled clinical trials, arthroscopic surgery, autologous chondrocyte implantation or microfracture have limited long term effect on the treatment of OA $[7,8]$. The challenge for researchers to develop disease-modifying $\mathrm{OA}$ treatments is, therefore, of paramount importance. Adult mesenchymal stem cells (MSCs) have emerged as a candidate cell type with great potential in regenerative med:cine [9]. MSCs are being investigated as a regenera. biologic agent because of their ability to differentiz... into multiple tissue types and to self-renew [10, 11].

The paracrine activity of MSCs is thougb to one of the major means by which these cells ediate a (1- $^{-}$ inflammatory, anti-apoptotic, anti-fibr tic, giogenic, mitogenic and wound healing propcrtres. The omplex interplay of the biological mediatr ss secreted by MSCs has been shown to be important regulating regeneration of a variety of damared or anured organs and tissues of the body. It has alsc whown that the precurser to the MSC is the nericyte which are the cells present on the microversels nd cosillaries throughout the body. These cells be wated" when an injury is recognized and detach become medicinal MSCs. An immune-mo u. ry effect is initiated where other cells are called to help $h$ the healing process while other secreter molecules will establish a regenerative microenvironme sy set ing up a trophic field [12].

S a s capable of suppressing an immune spo co bv suppressing the maturation of dendritic cells. $M \quad s$ may also restrain the T, B, and NK cell function in inflan nation. MSCs are involved in cross talk between the immune cells and as a result may present a novel approach for the treatment of various diseases [13].

The stromal vascular fraction (SVF) can be obtained from fat tissue and contains a variety of different types of cells including adipose-derived stem cells. Adiposederived stem cells or ADSCs are multi-potential in that they have the ability to differentiate into a variety of different types of tissue including but not limited to bone, cartilage, muscle, ligament, tendon and fat [14]. These cells have also been shown to express a variety of different growth factors and signaling molecules (cytokines), which recruit other stem cells to facilit e repair and healing of the affected tissue. ADSCs are angic renic in nature and can promote the growth of new $10 \mathrm{~d}$ vessels. ADSCs might play a role in $t^{\prime}$ local inflammatory process in the joint.

The SVF might play a role in the loc. inflammatory process in the joint. Studies ve shoyn that SVF exerts anti-inflammatory effer on ath chondrocytes and synoviocytes and the the ells are not dependent on adipose tissue sou as or do r. SVF has been shown to exhibit immonos ressive properties and release anti-inflamm y molv ales like IL-10, IL-1, receptor antagc ist I -1 ra), indoleamine 2,3-dioxygenase, transforming rowtn factor (TGF) $\beta$ and prostaglandin E? The celt in SVF seem to be able to sense and respon local environment in OA knees $[15,16]$. A strom vascular fraction can easily be isolated from fat tissue $\%$ approximately $30-90 \mathrm{~min}$ in a clinic setting ing a mini-lipoaspirate technique. The SVF contains a tixture of cells including ADSCs and growth fac$t_{0} / s$ and has been depleted of the adipocyte (fat cell) population. It has been shown that cells isolated from the SVF contain an abundance of CD34+ cells $[15,17]$. SVF can be used in a point of care setting for a variety of indications and is currently being used in thousands of clinics world-wide with varying degrees of success being reported. Adipose tissue is quickly becoming the preferred source for point of care treatments in clinic due to the high number of MSCs that can be obtained and the low number of leukocytes as compared to bone marrow. In addition, adipose tissue has a significantly higher amount of pericytes which are the precursors to MSCs [18-20].

Recent studies evaluating ADSCs as a potential for articular cartilage regeneration have shown the potential of the cells to develop into chondrogenic lineage [21]. Clinical studies have reported improvements in function and pain of the knee joint as well as increased cartilage thickness with a strong safety profile [22-27].

Adipose tissue has many advantages in comparison to bone marrow. Adipose can be easily obtained by standard liposuction under local anesthesia. Adipose tissue contains approximately 500-2500 times more mesenchymal stem cells compared to the same volume of bone marrow [20]. In addition, the number of stem cells available in the bone marrow decreases with age and the pool in adipose tissue is quite stable during life. Compared with bone marrow-derived cells, adipose tissue-derived cells are more genetically stable, have higher proliferative and 
differentiation capacity, have lower senescence ratio, and have longer telomere length $[28,29]$.

In one clinical study reporting on 18 patients (between the ages of 18 and 75), SVF from subcutaneous abdominal fat was injected intra-articularly into idiopathic osteoarthritic knees. The high dose injections $\left(1.0 \times 10^{8}\right)$ were associated with an improvement in pain, stiffness and function as measured by the WOMAC score with a mean reduction of $39 \%$ over a 6 month period. MRI examination found regeneration of articular cartilage in the medial femoral and tibial condyles as well as in the lateral femoral and tibial condyles and increased cartilage volume in the medial femoral and tibial condyles at 6 months. Arthroscopy before and 6 months after SVF injection demonstrated findings consistent with clinical and radiological outcomes showing the regeneration of articular cartilage with a thick, glossy white matrix and smooth surface well integrated with the sub chondral bone [24].

Another clinical study reported on 18 patients (6 men and 12 women) injected with SVF from the infrapatellar fat pad with a mean of 1.8 million cells (range $0.3 \times 10^{6}$ $2.7 \times 10^{6}$ ) along with approximately $3.0 \mathrm{ml}$ of platel $\mathrm{c}$ rich plasma with a mean of $1.28 \times 10^{6}$ platelets $/ \mathrm{ml}$ index scores decreased significantly $(\mathrm{p}<0.001)$ fro. 49.9 points preoperatively to 30.3 points at the final "lo up (range 24-26 months). Lysholm score imprrved nificantly from a mean preoperative value of $? .1$ poin 73.4 points, and similarly VAS scores de rea from 4.8 preoperatively to 2.0 at last follow us. In addity 1 , notable changes were detected in cartil ge MRI scores which improved from 28.3 points to 21.7 ints. Th is study suggested that intra-articular injection or r from infrapatellar fat pad is effective for re main and promoting new tissue growth [22]. The sar group had reported on an earlier study with $1 \mathrm{~m}$. $\mathrm{r}$ resu't's [30].

In one large tria $\angle 8)$, SVF was utilized in patients with grade \& degenerative osteoarthritis (OA). The tri nonstrated a strong safety profile with no severe dverse pits or systemic infection. In addition, nr patients developed cancer as a result of SVF therapy. najor ty of the patients demonstrated gradual im veme -12 months after the treatment. At least $-5 \%$ mase inprovement was noticed in $63 \%$ of patients ah t least $50 \%$ Score improvement was documented in 91\% patients after 12 months. The authors concluded that SVF therapy is a novel and promising treatment approach for patients with OA [26].

Adult stem cells require various growth factors to maintain their growth and engraftment. Recent studies have discussed the use of platelet rich plasma (PRP) as a rich source of growth factors. Platelets contain key growth factors such as platelet derived growth factor
(PDGF), transforming growth factor (TGF), fibroblast growth factor (FGF), and various interleukins (IL) which may contribute to the functionality of the stem cells [31]. Platelet released growth factors regulate endogenous hyaluronic acid (HA) synthesis, thereby rotecting the cartilage and lubricating the join [11]. 10 onh nces the secretion of HA and induces hepatoc frowth factor production by synovial fibr 'lasts isolated from arthritic patients. This study con ide he in ra-articular injection of SVF from fat anc the safety nd efficacy for the treatment of OA in comb ation w/th PRP.

\section{Methods}

The criteria for se tion we $\mathrm{e}_{\text {. }}$ patients age 50 or older who present wi a s, tomatic primary osteoarthritis of the knee definea oy daily pain for the previous 3 months, alge irs usage at least once a week, less than 30 min of mo ing suffness and a WOMAC score of $\leq 75$ in the target $k_{\imath}$. The radiographic eligibility criteria includear Radiographic Grading Scale of Osteoarthritis gl de 1 and 2 . The exclusion criteria were evidence of seconcary knee osteoarthritis, severe osteoarthritis int space width-JSW $<2 \mathrm{~mm}$ ), prior intra articular in, ctions within the previous 1 year prior to inclusion and patients with clinically significant systemic disease.

The Western Ontario and McMaster Universities Osteoarthritis Index (WOMAC) is a widely used measure of patient's subjective assessment of pain, joint mobility and physical disability. It evaluates three dimensions, namely pain, stiffness and physical function with 5, 2, and 17 questions respectively. Total maximum score is 96 and minimum is 0 . Each subscale is summated to a maximum score of 20,8 and 68 respectively [32].

The six-minute walking distance (6MWD) was carried out by marking off a $50 \mathrm{~m}$ distance in an interior hallway and asking subjects to walk as far as they can and as quickly as they can over $6 \mathrm{~min}$. The total distance was measured and recorded [33].

Antero-posterior radiographs of the knee joints were obtained with patients in a weight bearing position, joint fully extended, standing at $1 \mathrm{~m}$ from the X-Ray source, using previously published guidelines. Width was measured at the narrowest point of the joint space width (minimal JSW). This progression was defined by a JSW loss of more than $0.50 \mathrm{~mm}$ during the study, as previously reported [34].

MRI was completed with $1.5 \mathrm{~T}$ standard protocols of each individual joint in coronal sagittal and transverse plane. Maximum thickness of cartilage at posterior/ meniscal and patellar level measured at mid sagittal thru medial condyle was taken into account. The medial femoral cartilage of the affected knee was selected for measurement. Three regions of the medial femoral condyle 
were identified at the anterior patella femoral, meniscal and posterior condyle level. The point having maximum thickness in the sagittal section passing thru the middle was identified for measurement.

Etoricoxib with a dose limited $90 \mathrm{mg} \mathrm{BD}$ after meals was advised to patients for unbearable pain. If the pain was still uncomfortable then they were advised to take codeine in a dose of $30 \mathrm{mg}$ as needed and report the next day.

Tolerability and safety assessments included any symptoms and signs reported by the patient and also laboratory based hematological and biochemical assays. Synovial fluid was analyzed using microscopic examination at baseline and 2 years post procedure for atypical cell counts. Adverse events were categorized as isolated, intermittent or continuous depending on interference with the subject's daily activities as mild, moderate or severe. Possible causal relationship with the supplement in terms of Definite/Possible/Probable/Non Assessable/ None were assigned. The study was approved by institutional committee for stem cell research and therapy. All the patients were well informed and gave written consent to participate in the study.

\section{Isolation of stromal vascular fraction cells from adip tissue}

From each patient, approximately $100 \mathrm{ml}$ f $\mathrm{h}$ collected from the abdomen using a $3 \mathrm{~mm}$ - iration $\mathrm{n}^{-}$ nula with prior administration of tumes ent tion and placed into sterile disposable $250 \mathrm{mi}$ conical atrifuge tubes. The adipose tissue was wash $\mathrm{d}$ twice in phosphate buffered saline (PBS) and digestec sing collagenase at $37{ }^{\circ} \mathrm{C}$ for $30 \mathrm{~min}$ with agitation at $5 \ldots$ intervals. The suspension was then divided a. $50 \mathrm{ml}$ centrifuge tubes and centrifuged at $500 \times 1$ for $5 \mathrm{~min}$ to collect the SVF as a pellet. The pel was washed twice with normal saline to remo dual enzyme, and resuspended in PBS. The SV spension was filtered through a $100 \mu \mathrm{m}$ cell $\mathrm{st}_{\mathbf{L}} \quad$ er and centrifuged at $500 \times g$ for $5 \mathrm{~min}$. The supernatant $h$ discarded. The pellet was resuspended n normal saine and filtered through a $40 \mu \mathrm{m}$ cell strainer. nple; were taken to determine the cell quantit abilis and to culture and characterize the stem Ils.

\section{Cultu. of the cells}

The cells were washed thoroughly with DPBS/Gentamycin thoroughly twice. These were centrifuged at $1500 \mathrm{rpm}$ for $10 \mathrm{~min}$. Supernatant was discarded. The pellet was re-suspended in complete DMEM medium (Sigma) and plated in a T25 flask and incubated at $37{ }^{\circ} \mathrm{C}$ under $5 \%$ $\mathrm{CO}_{2}$. Media was changed every 3-4 days until the cells achieved $90 \%$ confluency. The cells were characterized through morphological evaluation and flow cytometry analysis.

\section{Morphological studies}

The cells were cultured in six well plates y 0 to $70 \%$ confluency in complete DMEM media ana were taken at different time intervals by an inve $r$ microscope at $20 \times$ magnification.

\section{Flow cytometry studies}

For flow cytometry, the cell were cyltured in six well plates in complete $\mathrm{DN}$ " $\mathrm{M}$, dia 0 80\% confluency. These were harveste $u s$ mild trypsin EDTA and washed with PBS Te cells ere incubated with fluorescently labeled ant dies CD90, CD34, CD73, CD45, CD105 and $H-D R$. It cells were processed for flow cytometry alys cusing BD FACS Calibur.

\section{Platele+ rich plas, a preparation}

Platelet a lasma was derived from the peripheral blood of the same donor as the adipose tissue. Briefly, $20 \mathrm{ml}$ of Jeripheral blood was collected into BD yellow vacuum tubes (ACD Solution $A$ ) and centrifuged at $80 \times g$ for $10 \mathrm{~min}$. The plasma fraction was collected and centrifuged at $1000 \times g$ for 5 min to obtain a platelet peliet. Most of the plasma was then removed, leaving $3 \mathrm{ml}$ plasma to resuspend the platelets.

\section{Statistical analysis}

Formal power calculations were not performed. Two tailed statistical analyses were performed and confidence intervals are presented with $95 \%$ degree of confidence. All statistical tests used a significance level of $\alpha \leq 0.05$.

\section{Treatments}

A total of ten patients over the age of 50 with idiopathic osteoarthritis of the knee were enrolled in the study. SVF cells were resuspended in $5 \mathrm{ml}$ of saline and combined with $3 \mathrm{ml}$ of PRP. A single injection of SVF and PRP was administered intra-articularly. At the baseline, patients were assessed for vital signs, laboratory tests, WOMAC score, 6MWD, radiological images of joint space width, and MRI measurement of articular cartilage thickness. Clinical status of all patients was closely monitored at baseline, at the time of SVF treatment, 1 week, $1,3,6$ months, and 1, 1.5 and 2 years after the SVF treatment. WOMAC score, $6 \mathrm{MWD}$ and laboratory tests were repeated at 3 and 6 months and 1, 1.5 and 2 years. XRAY and MRI were completed at 1 year. Clinical evaluation included medical history, physical examination, assessment of joint pain, number of analgesic drugs taken, joint stiffness and extent of joint movement, as well as any side effects possibly associated with SVF cell therapy. 


\section{Results}

A total of ten patients were treated with mean age of 58.4, height of $158.2 \mathrm{~cm}$ and weight of $72.6 \mathrm{~kg}$. Six patients were male and four were female. Seven patients had one knee treated and three had both knees injected. Fat harvested yielded an average nucleated SVF mean cell concentration of $1 \times 10^{6} / \mathrm{ml}$ of adipose tissue and viability of $87.4 \%$. The morphology of the cultured cells appeared to be like typical fibroblastic mesenchymal stem cells adhered to the plastic surface (Fig. 1a). Few clumps of the cells were observed. The flow Cytometry data show more than $98 \%$ positive expression of CD105, CD90 and CD73 and negative expression of CD45, CD34 and HLA DR (Fig. 1b).

Significant changes in the WOMAC scores were noted in both the subsets and the total after 2 years as compared to the baseline. A correlation between pain severity and disability was demonstrated by the WOMAC subscales. The WOMAC scale allows a detailed analysis of pain because patients score the pain severity while performing specific activities. Patients had a decreased functional ability most likely due to severe pain at baseline readings. The average total WOMAC score (Fig. 2 was 64 at the baseline and significantly reduced to at 3 months $(\mathrm{p}<0.01), 46$ at 6 months $(\mathrm{p}<0.01), 42$ at 1 year $(\mathrm{p}<0.01), 38$ at 1.5 years $(\mathrm{p}<0.01)$, $\mathrm{f}<1$ at 2 years $(\mathrm{p}<0.01)$.

WOMAC pain score during walking, ng stairs in bed, sitting or lying and standing wer als recorded. Patients demonstrated a significan reduction in pain (Fig. 2b) from 14 at baseline to 12 : 3 months $(\mathrm{p}<0.01)$, 11 at 6 months $(\mathrm{p}<0.01), 9$ at vear $(\mathrm{p}<0.01), 8$ at 1.5 years $(\mathrm{p}<0.01)$, and $\mathrm{Q}$ at 2 yeur. $(\mathrm{p}<0.01)$ post therapy. Stiffness score (Fig hich includes 17 parameters, showed reduction rom 6 at baseline to 5 at 3 months and $6 \mathrm{~m}$ ont $\quad(\mathrm{p}<.01)$, and 4 at $1,1.5$ and 2 years $(\mathrm{p}<0.01) \mathrm{Ph}_{\mathrm{h}}$ iran . ction score (Fig. $2 \mathrm{~d}$ ) of 50 from the baseli reduc to 44 at 3 months $(\mathrm{p}<0.01)$, 38 at 6 mon hs $<0.01), 32$ at 1 year $(\mathrm{p}<0.01), 30$ at 1.5 years $(<0.01), 1 / 31$ at 2 years $(\mathrm{p}<0.01)$.

Figur 3 shows the results of the 6MWD. Patients walked. 1vera e of 1310 feet at baseline and demonstr a st. cically significant improvement $(\mathrm{p}<0.01)$ 3 a 16 months and $1,1.5$, and 2 years post treatment. In Adition, the requirement of pain medication post inject on reduced from twice a week at baseline to once a week in 3 patients at 3 months, 5 patients at 6 months, 7 patients at 1 year, 8 patients at 1.5 years and 5 patients at 2 years.

MRI evaluation demonstrated that cartilage thickness improved by at least $0.2 \mathrm{~mm}$ in six patients. Thickness remained unchanged in two patients at 1 year, which indicated chondro-protective and anti-inflammatory disease stabilization effect. However, in two patients it decreased by $0.2 \mathrm{~mm}$. At 2 years post injection, one patient received a follow up MRI which showed that the increased cartilage volume was maintained (Fig. 4). Figures 5, 6, 7, 8 show MRIs at baseline ard 1 year post treatment.

Overall, all of patients were pleased with th results. They reported that their in levels gradually reduced, especially after 3 morths. 'ore mportantly, the procedure demonstrated strong sa ty profile with no severe adverse events or mplicat ons reported. One patient complained of $p$, $n$ a wo ing due to reactive synovitis which respo dea th complete resolution with conservative treatm $\mathrm{nt}$.

\section{Safety evaluat:}

Two years ost arocedure, synovial fluid examination showed no at, "cal cells (Table 1). However, the analysis suggerted that $\mathrm{t}_{\mathrm{s}}$ atment helped to restore synovial fluid properitu, ore synovial metabolism and reduce cartilage pat $\operatorname{logy}$. Eight patients demonstrated a reduction in atypica/cells. Average cell counts were 1226 cells/ $\mu \mathrm{l}$ at seline and reduced to $845 \mathrm{cells} / \mu \mathrm{l}$ at 2 years. The hemato gical and biochemical parameters recorded before and after 2 years of the treatment also did not show any abnormalities (Table 2).

\section{Discussion}

Osteoarthritis is a chronic progressive degenerative disease associated with cartilage loss and degeneration. Current treatments are limited and advanced disease relies on total joint replacement. Total joint replacement may be associated with serious and life threatening complications including increased risk of infection, thromboembolism, myocardial infarction, stroke, and even death post-surgery. In addition, the life span of the prosthesis is limited [34].

This preliminary clinical study showed that SVF cells freshly isolated from adipose tissue, combined with PRP and administered intra-articularly, demonstrate healing potential in patients with degenerative OA. This is consistent with previously published results from both preclinical and clinical studies. Patients demonstrated significant improvements in their degenerative OA leading to a better quality of life. These improvements included a clinically significant reduction in pain.

Pain functional status of the knee was improved 12 months post injection in all patients and this improvement was maintained at the 2 year time point. Some patients showed improvements as early as 3 and 6 months after the injection of SVF and PRP. This confirms the mechanism of action of regenerative medicine to be a cascade of events that occur over time. These 


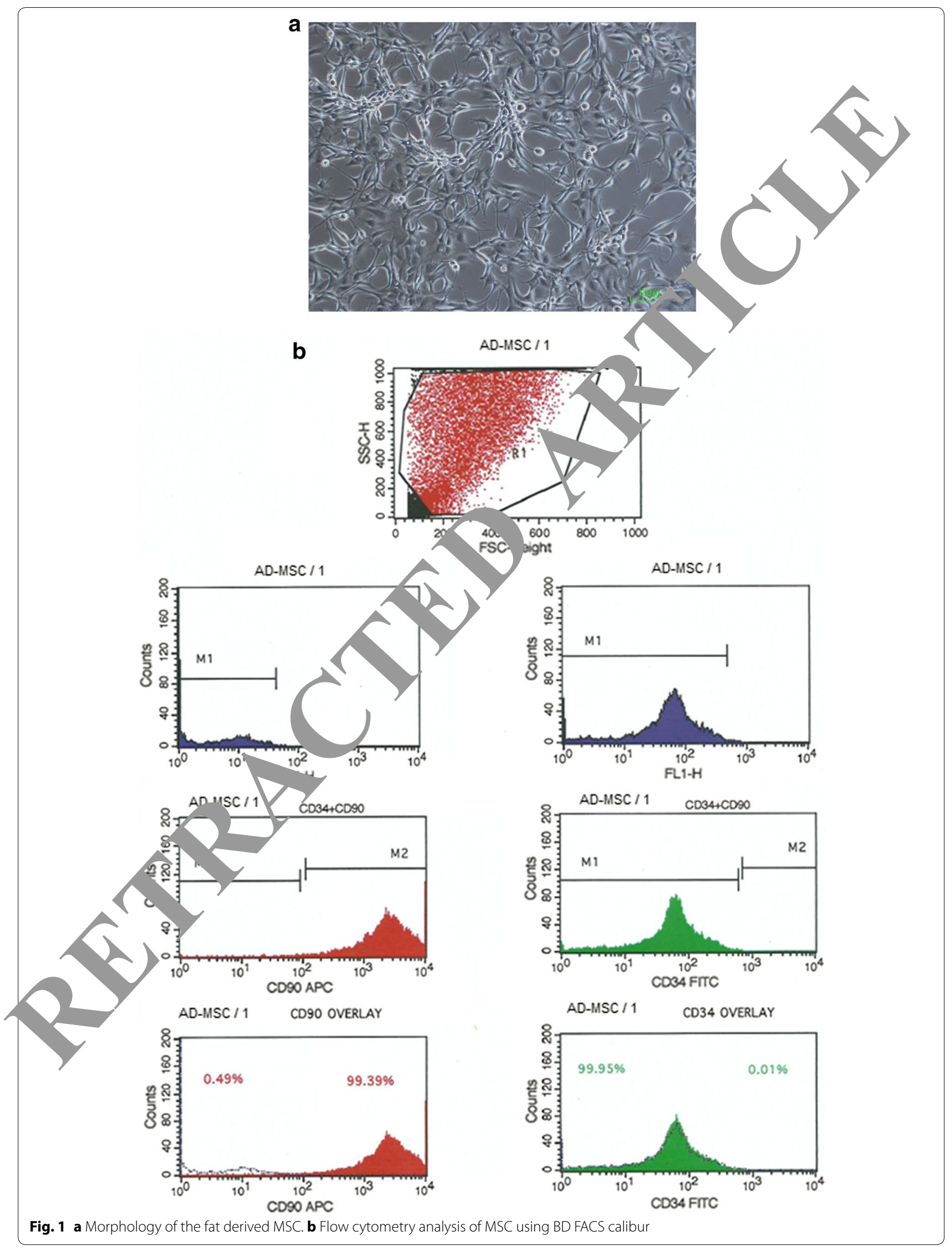




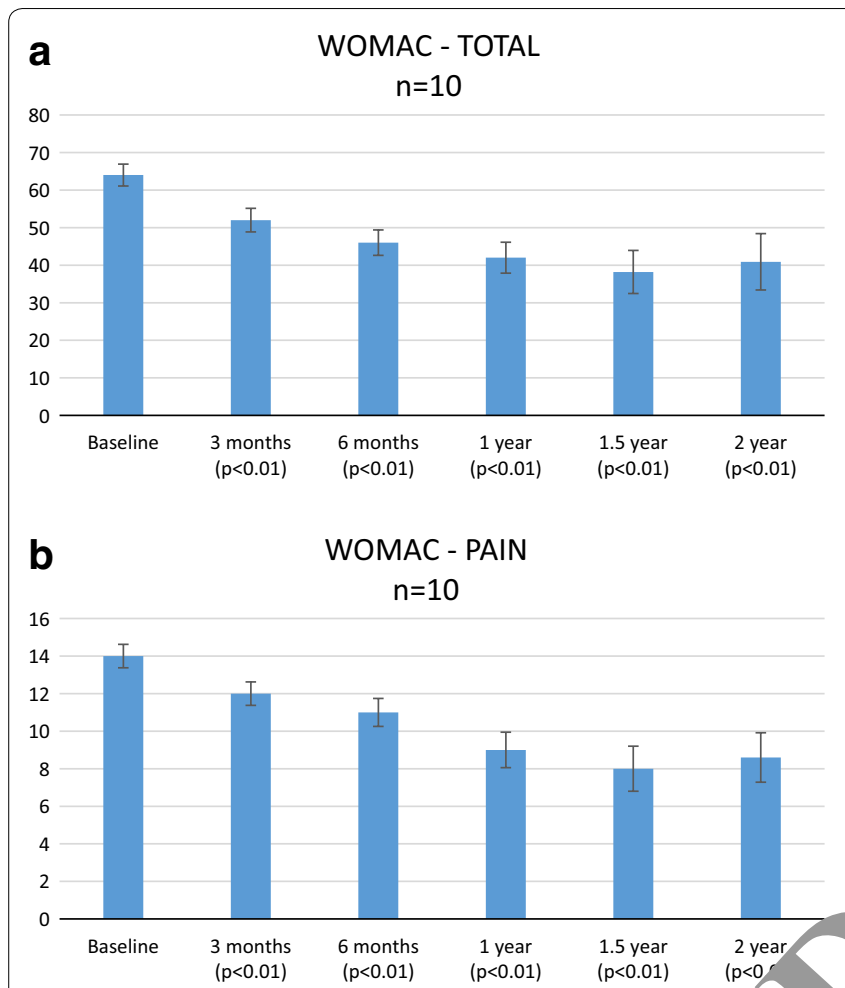

Fig. 2 a Total WOMAC score. b WOMAC pain score. c WOMAC s"ffness
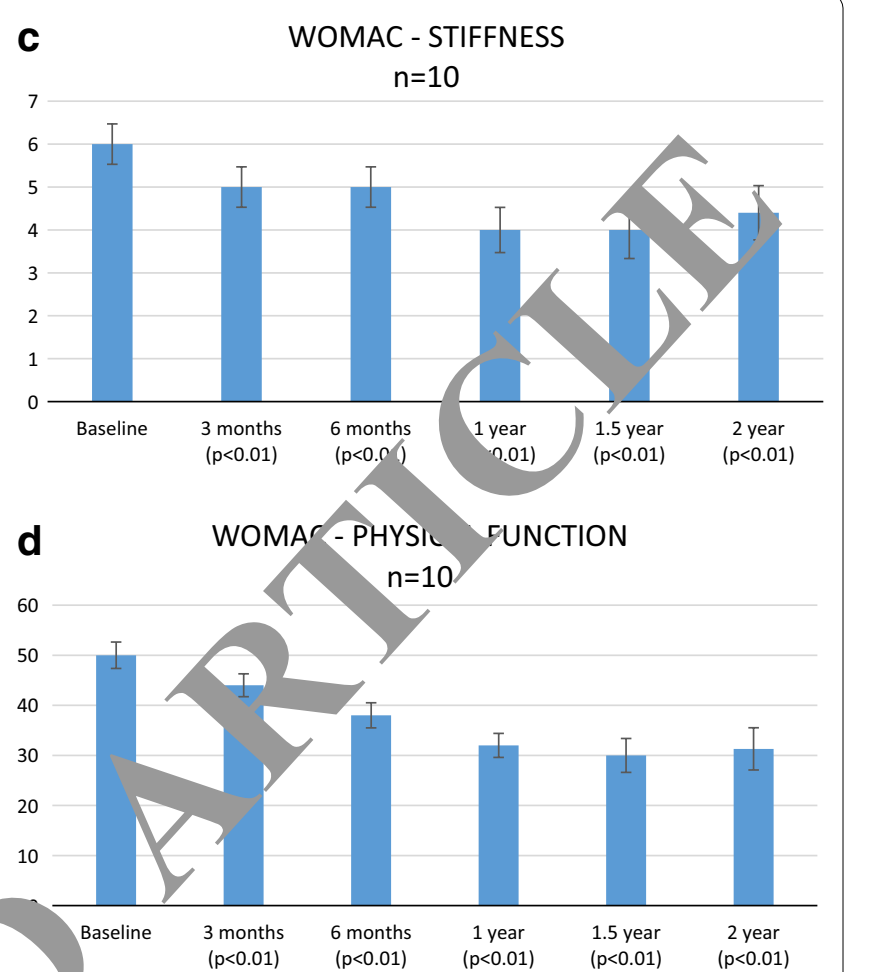

d NOMAC physical function score

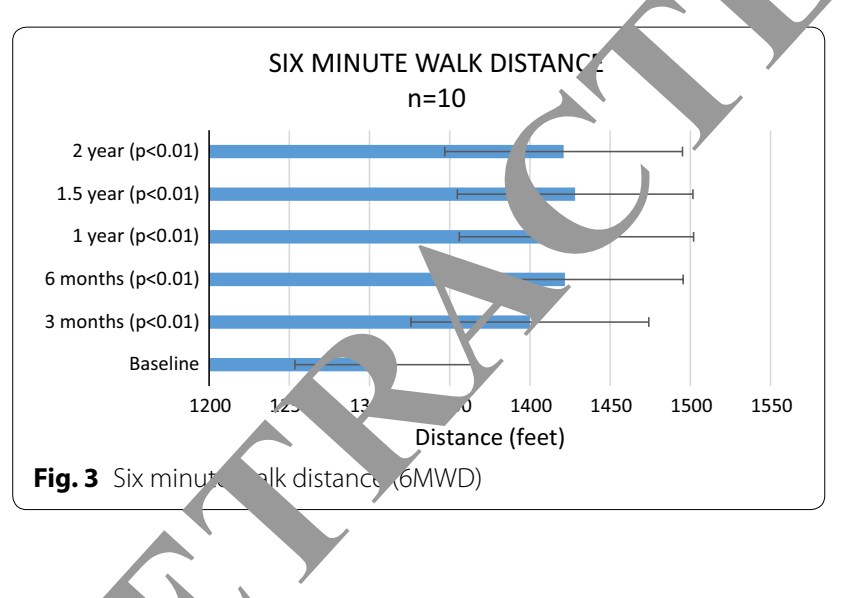

events ace immuno-modulatory effect that can le $o$ tis remodeling. The anti-inflammatory and in duction effects may be attributed to the soluble gi th factors secreted from the SVF or ADSCs [32]. Grow 1 factors from ADSCs may be continuously produced after injection of these cells into the joint creating a cascade of events that lead to healing. It is unclear at this point whether the cells injected actually differentiate into new cartilage or the cells injected stimulate native tissue to heal by creating a paracrine effect. Native cells may be called to the area to help remodel the damaged tissue leading to an increase in cartilage volume [11].
The autologous SVF and PRP injections also significantly reduced the requirement of pain medication in 8 out of 10 patients. These medications are often associated with undesired side effects and although it may mask the pain, it does not help the underlying disease. In addition, clinical improvement corresponded well with improvement on MRI imaging. We were able to demonstrate safety with no serious side effects reported during the 2 year follow-up. One patient experienced local pain and swelling at the lipo-aspiration site, but those symptoms were short lasting and were well controlled with common analgesics. Only one patient developed synovitis in the joint which resolved with conservative treatment.

Freshly isolated cells may represent a safe and efficacious way to manage patients with osteoarthritis. An immediate autologous transplantation can prevent complications related to the reduced quality of the transplanted cells such as pre-aging (telomere shortening), reduced viability, or dedifferentiation/reprogramming that is associated with in vitro-cultivation [35]. In addition, the risk for infection is reduced by decreasing the ex vivo time period. Although in this study cells isolated from SVF were also evaluated by culture and characterization to further establish existence of MSCs in the fraction, cells isolated from SVF expressed characteristics distinctive for MSC identification such as plastic 


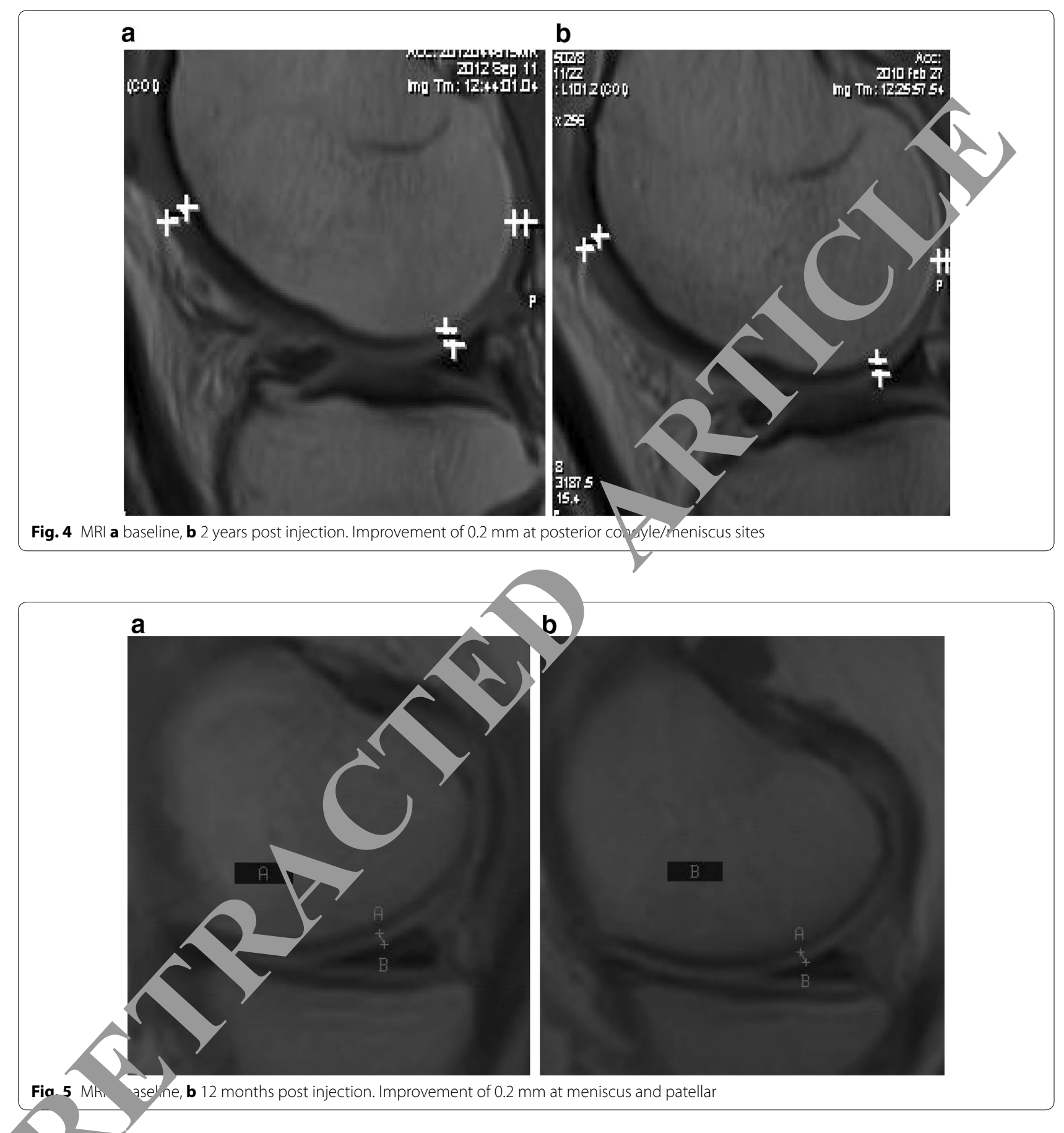

ad. ance with typical fibroblast like morphology and positı.e MSC markers by flow cytometry. Overall the entire treatment is a relatively simple procedure which is inexpensive and can be completed in clinic on an outpatient basis. Numerous studies are currently in progress to clarify some of the questions that still remain unanswered regarding the long-term durability of these procedures and possible modifications to achieve better results. Here we present preliminary data suggesting safety and long term efficacy of a cost effective outpatient procedure of administration of SVF and PRP in the knee.

This study lacks a placebo control due to very small sample size. The relationship of age, sex, weight and the severity of OA could not be clearly ascertained. In addition, MRI evaluation should have been more extensive with three-dimensional magnetic resonance observation of cartilage repair tissue (MOCART) or other scaling methods to quantify the regeneration in 

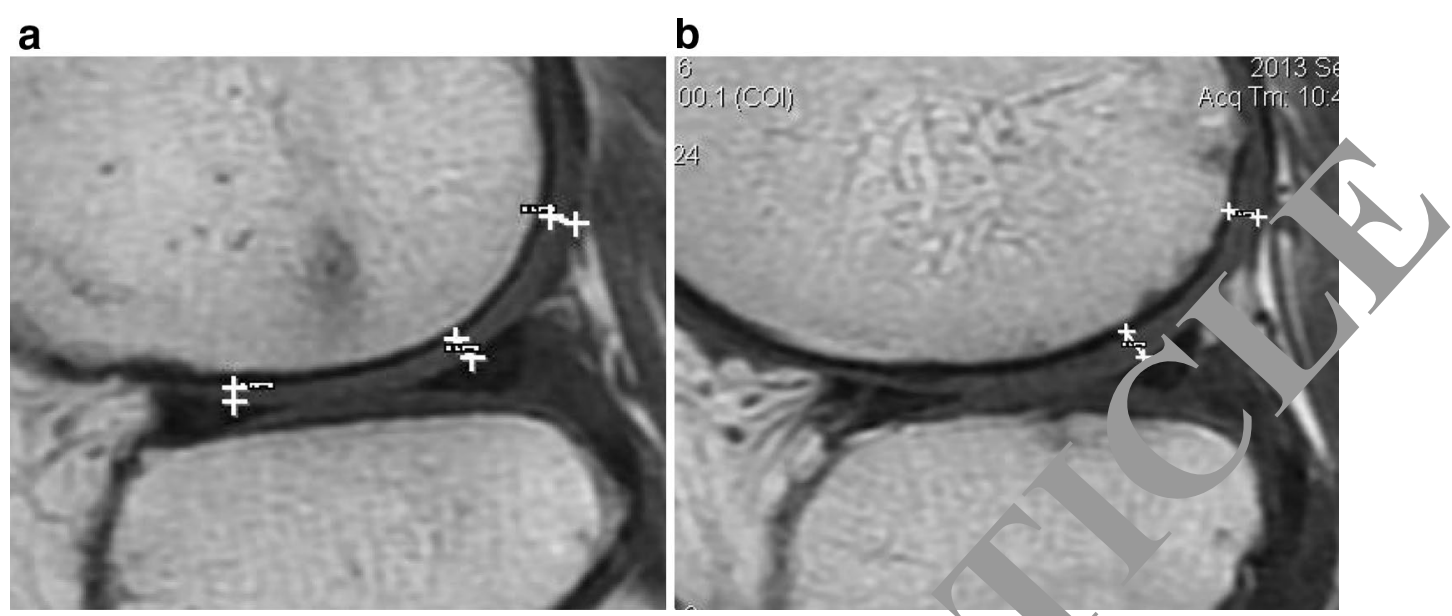

Fig. $6 \mathrm{MRl}$ a baseline, b 12 months post injection. Improvement of $0.2 \mathrm{~mm}$ at posterior and $\mathrm{m}$ cus. No cy iges noted at patella/femoral level

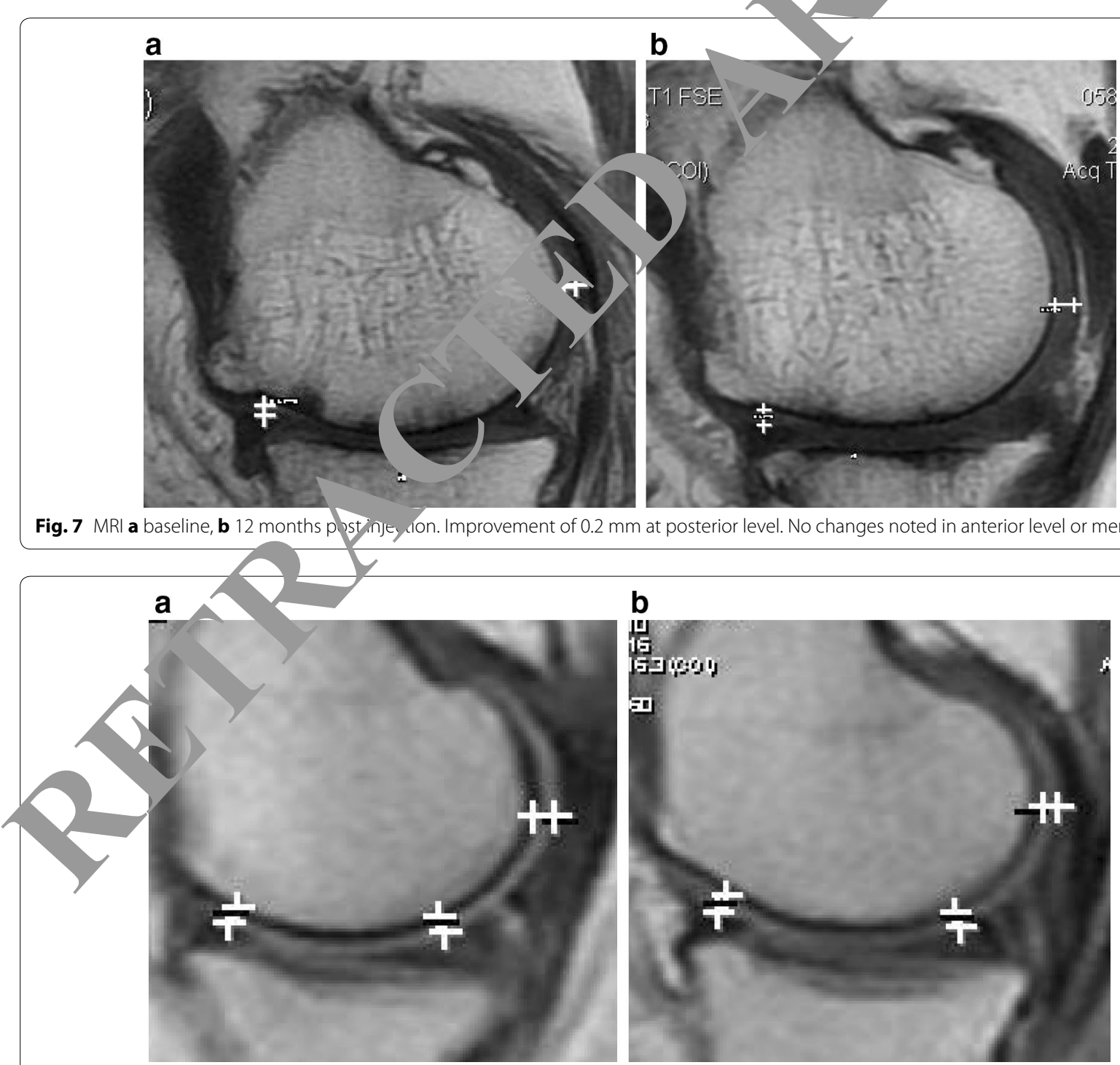

Fig. $8 \mathrm{MRl}$ a baseline, $\mathbf{b} 12$ months post injection. Improvement at all levels 
Table 1 Number of atypical cells/ $\mu \mathrm{l}$

\begin{tabular}{ll}
\hline Baseline & At 2 year follow up \\
\hline 1440 & 490 \\
680 & 460 \\
860 & 560 \\
1200 & 800 \\
1600 & 880 \\
1780 & 1260 \\
460 & 480 \\
1060 & 440 \\
1380 & 1260 \\
1800 & 1820 \\
Average & \\
1226 & 845 \\
\hline
\end{tabular}

Table 2 Hematological and biochemical parameters

\begin{tabular}{|c|c|c|}
\hline Parameter & Baseline & 2 years \\
\hline RBC count, $10^{6} / \mu \mathrm{l}$ & $4-4.6$ & $4.2-4.6$ \\
\hline Hemoglobin, g/dl & $12-14.2$ & 11.6 \\
\hline PCV heamtocrit, \% & $38-40$ & \\
\hline 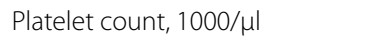 & $260-340$ & \\
\hline White blood cell count, 1000/ $\mu$ l & $6.4-8.4$ & \\
\hline \multicolumn{3}{|l|}{ WBC differential count } \\
\hline Neutrophils, \% & $56-70$ & \\
\hline Eosinophils, \% & $2-6$ & \\
\hline Lymphocytes, \% & & \\
\hline Monocytes & & $1-3$ \\
\hline Basophils & & 0 \\
\hline CRP & & $<1$ \\
\hline ESR & & $10-14$ \\
\hline SGPT, IU/I & & $28-38$ \\
\hline SGOT, IU/I & & $18-20$ \\
\hline Serum creatinin & $0.5-0.9$ & $0.6-0.9$ \\
\hline Glucose (F) & $90-110$ & $86-108$ \\
\hline
\end{tabular}

cartilage $f$ llowing $c$ treatment. Further it is not clear if the $r$ ren rated cartilage is fibro cartilage or hyaline as arthrosce bic psy was not possible in any of subjects. Te tensiv pathologic changes in OA were identified "ic "ure" not only in articular cartilage but also in the anges of synovial membrane. Changes in subchondral bjone and joint capsules were not investigated.

\section{Conclusions}

SVF combined with PRP has a great potential as a therapeutic agent in regenerative medicine especially in orthopedic conditions. The high numbers of MSCs in SVF make it a suitable source for cellular medicine. Preliminary studies suggest that it is a safe and effective method for treating osteoarthritis. Both qualitative and quantitative measurements showed statistically significant improvements during the follow up period of 2 years. Additional studies with larger patient numbers and control subjects are needed to confirm the above results. Another limitation of this study is the co of two modalities is unclear. Future studies tr randomized groups considering each th apeutic agent separately and combined against a co tron waranted. This clinical study of a combined intra-artic ar injection of SVF and PRP into the knee iggests a promising minimally invasive therapy fo $\mathrm{OA}$ iants.

\section{Abbreviations}

SVF: stromal vascular fraction; derived stem/strom IIs; MSC: $n$ senchymal stem cell; WOMAC:Western Ontario and MC aster niversities Osteoarthritis Index; 6MWD: six-minute walk distance, $\mathrm{N}$. Stic resonance observation of cartilage repair tissue; SAE: severe a rse event; OA: osteoarthritis.

\section{Authors}

$H B$, JL desi nef trin protocol and $K C$ analyzed the data. $H B$ was responsible for procedules. PV performed laboratory culture of MSCs and characterization of the cells by microscopy and flow cytometry. DA analyzed the radiographs. KC and PV wrote the manuscript. PK helped to coordinate the study. All ors read and approved the final manuscript.

4v chor details

RegennMed Research and Therapeutics LLP, Chattarpur, Delhi, India. ${ }^{2}$ US Stem Cell, Inc, Sunrise, FL, USA. ${ }^{3}$ Advance Health Institute Mayaguez, Puerto Rico, USA. ${ }^{4}$ Mercy Medical Centre, Roseburg, OR, USA. ${ }^{5}$ Department of Virology and Immunology, Haffkine Institute, Mumbai, Maharashtra 400012, India. ${ }^{6}$ Regenerative Medicine Institute, Tijuana, Mexico. ${ }^{7}$ Mother Cell Spinal Injury \& Stem Cell Research, Anupam Hospital, Second Floor, Kashipur Bypass Road, Rudrapur, Uttarakhand 263153, India.

\section{Acknowledgements}

This study was funded by Anupam hospital and approved by the Institutional Committee for Stem Cell Research and Therapy (Trial AAH/02/12). In vitro culture and characterization studies were conducted at RegennMed Research and Therapeutics Delhi.

Competing interests

KC is an officer of US Stem Cell, Inc.

\section{Availability of data and materials}

The datasets during and/or analysed during the current study available from the corresponding author on reasonable request.

\section{Consent for publication}

All patients were consented and agreed to participate in the study and to have their data published.

\section{Ethics approval and consent to participate}

The trial was approved by the ethics committee of Anupam Hospital called the Institutional Committee for Stem Cell Research and Therapy (Trial $\mathrm{AAH} / 02 / 12$ ).

\section{Funding}

This study was partially funded by Anupam Hospital and US Stem Cell, Inc.

\section{Publisher's Note}

Springer Nature remains neutral with regard to jurisdictional claims in published maps and institutional affiliations. 
Received: 5 May 2017 Accepted: 13 June 2017

Published online: 19 June 2017

\section{References}

1. Loeser RF, Goldring SR, Scanzello CR, Goldring MB. Osteoarthritis: a disease of the joint as an organ. Arthritis Rheum. 2012;64:1697-707.

2. Sun HB. Mechanical loading, cartilage degradation and arthritis. Ann NY Acad Sci. 2010;1211:37-50.

3. Osteoarthritis: national clinical guideline for care and management in adults. London: Royal College of Physicians; 2008

4. Altman RD, Hochberg MC, Moscowitz RW, Schnitzer T. Recommendations for the medical management of osteoarthritis of the hip and knee. Arthritis Rheum. 2000:43:1905-15.

5. Jordan KM, Arden NK, Doherty M. EULAR recommendations 2003: an evidence based approach to the management of knee osteoarthritis: report of a task force of the standing committee for international clinical studies including therapeutic trails (ESCISIT). Ann Rheum Dis. 2003;62:1145-55.

6. Brown GA. AAOS clinical practice guideline: treatment of osteoarthritis of the knee: evidence-based guideline. J Am Acad Orthop Surg. 2013;21:577-9.

7. Kirkley A, Birmingham TB, Litchfield RB, Giffin JR, Willits KR, Wong CJ Feagan BG, Donner A, Griffin SH, D'Ascanio LM. A randomized trial of arthroscopic surgery for osteoarthritis of the knee. N Engl J Med. 2008;359:1097-107.

8. Knutsen G, Engebretsen L, Ludvigsen TC, Drogset JO, Grontvedt T, Solheim E, Strand T, Roberts S, Isaksen V, Johansen O. Autologous chondrocyte implantation compared with microfracture in the knee. A randomized trial. J Bone Joint Surg Am. 2004;86:455-64.

9. Hematti $\mathrm{P}$, Keating A. Mesenchymal stromal cells in regenerative medicine: a perspective. In: Hematti P, Keating A, editors. Mesenc mal stromal cells. Biology and clinical applications. New York: Hum na Press; 2013. p. 3-16

10. Sato M, Uchida K, Nakajima H, Miyazaki T, Guerrero AR, W-anab Roberts S, Baba H. Direct transplantation of mesenchymal tem cells in knee joints of Hartley strain guinea pigs with spont ne osteoarth/tis. Arthritis Res Ther. 2012;14:R3.

11. Noth U, Ander F, Steinert I. Technology insight auuit mesenci mal stem cells for osteoarthritis therapy. Na Clin Pract Rheumatol. 2008;4(7):371-80

12. Caplan Al, Correa D. The MSC: an injury drug Cell sem Cell. 2011;9(1):11-5.

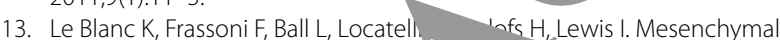
stem cells for treatment of steroid-res istar 1, , ere, acute graft-versushost disease: a phase II stud-ancet. 208;371:1579-86.

14. Strem BM, Hicok KC, Zh M M, U I, Alfo so Z, Schreiber RE. Multipotential differentiation $\quad$ ipo derived stem cells. Keio J Med. 2005;54:132-41.

15. Bunnell B. Adip o-derived Su Cells for regenerative medicine. Circ Res. 2007:01:1240-6u

16. Rehman I Traktuev $\quad$, Merfeld-Clauss S, Temm CJ, Bovenkerk JE, Pell C, Johnstone B, Considi, RV, March KL. The secretion of angiogenic and ti-ap optotic factors by human adipose stromal cells. Circulation. 2004, '0): 2918

17. can G, A, in SM, Leddy HA, Robey PG, Storms RW, Gimble JM. Surface pi ein chan cterization of human adipose tissue-derived stromal cells. J 2001;189(1):54-63.

־ktuevDO, Merfeld-Clauss S, Li J, Kolonin M, Arap W, Pasqualini R, John-

$\mathrm{BH}$, March KL. A population of multipotent CD34-positive adipose stromal cells share pericyte and mesenchymal surface markers, reside in a periendothelial location, and stabilize endothelial networks. Circ Res. 2008;102(1):77-85.
19. Jang Y, Koh YG, Choi YJ, Kim SH, Yoon DS, Lee M, Lee JW. Characterization of adipose tissue-derived stromal vascular fraction for clinical application to cartilage regeneration. Vitro Cell Dev Biol Anim. 2015;51(2):142-50.

20. Aust I, Devlin B, Foster SJ, Halverson YD, Hicok K, du Laney T. Yield of human adipose-derived adult stem cells from liposuction aspirates. Cytotherapy. 2004;6:7-14

21. Estes BT, Diekman BO, Gimble JM, Guilak F. Isolation a adip 'se-derived stem cells and their induction to a chondrogenic pher Nat otoc. 2010;5:1294-311.

22. Koh YG, Jo SB. Mesenchymal stem cells injec' ons improve sy riptoms of knee osteoarthritis. Arthroscopy. 2013;29(4). 55 .

23. van Lent PLEM, ven den Berg WB. Meser hyma m ceil therapy in osteoarthritis: advanced tissue repai or interventio vith smouldering synovial activation? Arthritis Res Th 2013;15:112.

24. Jo CH, Lee YG, Shin WH, Kim H/Cha Veong EC, Kim JE, Shim H, Shin JS, Shin IS. Intra-articular injecti fol me al stem cells for the treatment of osteoarthritis of the kn, proof-of-concept clinical trial. Stem Cells. 2014:32:1254-66

25. Wang W, He N, Fenc, $V$, Zhang L.,Wang F, He J, Zhu T, Wang S, Qiao W, Li S, Zhou G, Zh. ng L, _, Cao W. Human adipose-derived mesenchymal progen- cells eng, Into rabbit articular cartilage. Int J Mol Sci. 2015;16 120\% 91.

26. Michalek, ste $\angle L$, Proefrock K, Petrasovic M, Rybar J, Capkova M, Chaloupka Parinskas A, Michalek J Sr, Kristek J, Travnik J, Jabandziev P, Gibulka M, Holo I, Jurik M, Skopalik J, Kristkova Z, Dudasova Z. Autologou tissue-derived stromal vascular fraction cells application in patie ts y/um, steoarthritis. Cell Transplant. 2015. doi:10.3727/0963689 $15 \times 68160$.

27. Bui KH, I Aong TD, Nguyen TN, Nguyen TD, Le VT, Mai VT, Phan NL, Le DM, Ngoc NK, Phan PV. Symptomatic knee osteoarthritis treatment using autologous adipose derived stem cells and platelet-rich plasma: a clinical study. Biomed Res Ther. 2014;1:2-8.

Strioga M, Viswanathan S, Darinskas A, Slaby O, Michalek J. Same or not the same? Comparison of adipose tissue-derived versus bone marrow-derived mesenchymal stem and stromal cells. Stem Cells Dev. 2012;21:2724-52.

29. Mirsaidi A, Kleinhans KN, Rimann M, Tiaden AN, Stauber M, Rudolph KL, Richards PJ. Telomere length, telomerase activity and osteogenic differentiation are maintained in adipose-derived stromal cells from senile osteoporotic SAMP6 mice. J Tissue Eng Regen Med. 2012:6:378-90.

30. Koh Y-G, Choi Y-J. Infrapatellar fat pad-derived mesenchymal stem cell therapy for knee osteoarthritis. Knee. 2012;19(6):902-7. doi:10.1016/j. knee.2012.04.001.

31. Frechette JP, Martineau I, Gagnon G. Platelet-rich plasmas: growth factor content and roles in wound healing. J Dent Res. 2005;84:434-9.

32. Bellamy N, Buchanan WW. Validation study of WOMAC: a health status instrument for measuring clinically important patient relevant outcomes to anti-rheumatic drug therapy in patients with osteoarthritis of the hip or knee. J Rheumatol. 1988;15:1833-40.

33. Lequesne M, Brandt K, Bellamy N, Moskowitz R, Menkes CJ, Pelletier JP. Guidelines for testing slow acting drugs in osteoarthritis. J Rheumatol Suppl. 1994;41:65-71.

34. Schrama JC, Espehaug B, Hallan G, Engesaeter E. Risk of revision for infection in primary total hip and knee arthroplasty in patients with rheumatoid arthritis compared with osteoarthritis: a prospective, populationbased study on 108,786 hip and knees joint arthroplasties from the Norwegian Arthoplasty Register. Arthritis Care Res. 2010;62:473-9.

35. Bernardo ME, Locatelli F, Fibbe WE. Mesenchymal stromal cells: a novel treatment modality for tissue repair. Ann NY Acad Sci. 2009;1176:101-17. 